\title{
TEKNIK BIOREMEDIASI SEBAGAI ALTERNATIF DALAM UPAYA PENGENDALIAN PENCEMARAN AIR
}

\author{
Bambang Priadie* \\ Peneliti Muda Bidang Teknik Lingkungan SDA \\ *) Pusat Litbang Sumber Daya Air, Kementerian PU. Jl. Ir. H. Juanda No. 193 Bandung 40153. Tlp: 022 \\ 2501083, 2504035, Fax: 022 2500163, Email: bpriadie@yahoo.com
}

\begin{abstract}
ABSTRAK
Walaupun telah diberlakukan berbagai macam kebijakan dan peraturan terkait dengan pengendalian pencemaran air, namun penurunan kualitas badan air masih terus berlangsung. Hal ini disebabkan karena lemahnya pengawasan dan penegakan hukum maupun teknologi pengendalian pencemaran air yang berbasis pembubuhan bahan kimia masih belum bisa memenuhi kriteria yang diberlakukan. Tulisan ini menguraikan proses bioremediasi sebagai alternatif dalam upaya pengendalian pencemaran air, meliputi: isolasi, pengujian degradasi zat pencemar, dan perbanyakan bakteri. Hasil isolasi dan identifikasi yang berasal dari "bakteri indigenous" didapatkan: Microccocus, Corynebacterium, Phenylo- bacterium, Enhydro- bacter, Morrococcus, Flavobacterium, Bacillus, Staphylococcus, dan Pseudomona, yang dapat mendegradasi logam $\mathrm{Pb}$, nitrat, nitrit, bahan organik, sulfida, kekeruhan, dan amonia. Sedangkan dari bakteri "commercial product" didapatkan jenis: Bacillus, Pseudomonas, Escherichia, serta enzym Amylase, Protease, Lipase, Esterase, Urease, Cellulase, dapat mendegradasi pencemar organik, nitrogen, fosfat, maupun kontrol pertumbuhan alga. Perbanyakan bakteri dari isolat bakteri indigenous dapat dikerjakan di laboratorium sedangkan bakteri "commercial product" bisa didapatkan di pasaran umum.
\end{abstract}

Kata Kunci : bioremediasi, isolasi, pengujian, identifikasi, perbanyakan bakteri

\section{ABSTRACT}

Although various policies and regulations related to water pollution control has been enacted, decreasing of water quality in water bodies are still ongoing. This is due to the weakness of monitoring and enforcement practices, as well as pollution control technologies in water-based chemicals, can not achieve the affixing standard. This paper aims to examine the process of bioremediation technologies, include: isolation, degradation test, identification, and bacterial multiplication. Isolation and identification results of "indigenous bacteria" includes: Microccocus, Corynebacterium, Phenylo-bacterium,-bacter Enhydro, Morrococcus, Flavobacterium, Bacillus, Staphylococcus, and Pseudomonas, which can degrade the metals $\mathrm{Pb}$, nitrate, nitrite, organic matter, sulfide, turbidity, and ammonia. Where as the bacteria "commercial product" includes: Bacillus, Pseudomonas, Escherichia, and the enzymes amylase, protease, lipase, esterase, Urease, Cellulase, may degrade organic pollutants, nitrogen, phosphate, or control algae growth. Multiplication of bacteria from the indigenous bacterial isolates can be done in the laboratory while the commercial bacterial product can be found in the general market.

Keywords: bioremediation, isolation, bacterial testing, identification, bacterial multiplication

\section{PENDAHULUAN}

Kontaminasi bahan pencemar yang berasal dari aktivitas industri, pertanian, peternakan, maupun kegiatan rumah tangga telah menyebabkan terjadinya penurunan kualitas air yang signifikan pada badan air seperti sungai, danau dan waduk. Walaupun saat ini telah diberlakukan berbagai macam kebijakan dan peraturan terkait dengan pengendalian pencemaran air, diantaranya: PP No. 82 tahun 2001 dan Permen LH No. 13 Tahun 2010, namun lemahnya praktek 
pengawasan dan penegakan hukum menyebabkan penurunan kualitas air di badan air terus berlangsung. Status Lingkungan Hidup Indonesia (KLH, 2010) melaporkan bahwa sekitar $74 \%$ sungaisungai besar di Pulau Jawa tidak memenuhi Kriteria Air Kelas II. Selain itu, data hasil pemantauan 29 sungai di Jakarta menunjukkan bahwa 24 sungai telah mempunyai nilai Indeks Kualitas Air (IKA) yang buruk, dan hanya 5 sungai mempunyai nilai IKA sedang (BPLHD DKI Jakarta, 2002). Kondisi yang sama juga ditunjukkan dari hasil pemantauan 40 situ di Jakarta dimana didapatkan 83\% situ di DKI Jakarta juga mempunyai nilai IKA yang buruk (Diana 2005). Artinya, badan air, yaitu sungai dan danau telah dijadikan sebagai tampungan berbagai macam limbah dan telah mengalami penurunan kualitas air yang signifikan. Hal ini menandakan diperlukannya upaya yang berkesinambungan dalam rangka pengendalian dan pencegahan pencemaran air melalui upaya teknologi pencegahan dan penanggulangan pencemaran air yang sesuai dengan UU No:7/2004 tentang sumber daya air (SDA), pasal 20 ayat 1 dan 2 yang menyatakan bahwa konservasi SDA dilakukan untuk menjaga daya tampung dan fungsi SDA sehingga diharapkan sumber daya air yang ada dapat dimanfaatkan secara efisien dan berkelanjutan.

Saat ini upaya pengendalian pencemaran air pada umumnya dilakukan melalui teknologi pencegahan dan penanggulangan pencemaran air dengan pemilihan teknologi yang mempertimbangkan karakteristik air limbah dan standar kualitas efluen-nya. Teknologi yang dipilih diharapkan mampu mengubah kualitas efluen (effluent-standard) sehingga dapat memenuhi standar kualitas badan air penerima (stream-standard) yang dapat diaplikasikan secara maksimal agar dapat melindungi lingkungan serta memberikan toleransi bagi pembangunan industri. Acuan stream standard saat ini adalah standar yang ditetapkan pada badan air sesuai dengan peruntukannya, yaitu PP No. 82 Th. 2001, sedangkan acuan effluent standard adalah Baku Mutu yang ditetapkan pada limbah yang telah diolah dari unit-unit IPAL atau keseluruhan unit-unit IPAL yang mengacu pada Kep.Men LH No. 51/MENLH/10/1995. Namun demikian, karena mengingat pengolahan air limbah yang dilakukan pada umumnya melalui penambahan bahan kimia (misalnya bahan koagulan) yang harganya semakin meningkat dan dikhawatirkan adanya resiko dan sejumlah hasil akhir yang tidak dikehendaki maka alternatif penambahan koagulan yang berasal dari mikroorganisma bisa dijadikan pilihan (Buthelezi et al., 2009). Pada perkembangannya, perencanaan teknologi effluent-standard dan stream-standard mulai memperkenalkan metoda bioremediasi yang telah memperoleh perhatian yang cukup besar dari berbagai kalangan. Sehingga tulisan ini bertujuan untuk mengkaji proses bioremediasi dalam rangka teknologi pengendalian badan air tercemar yang meliputi: isolasi bakteri, pengujian bakteri dalam mengdegradasi zat pencemar, identifikasi bakteri, dan perbanyakan bakteri.

\section{BIOREMEDIASI}

Bioremediasi merupakan penggunaan mikroorganisme yang telah dipilih untuk ditumbuhkan pada polutan tertentu sebagai upaya untuk menurunkan kadar polutan tersebut. Pada saat proses bioremediasi berlangsung, enzim-enzim yang diproduksi oleh mikroorganisme memodifikasi struktur polutan beracun menjadi tidak kompleks sehingga menjadi metabolit yang tidak beracun dan berbahaya. Sehubungan dengan bioremediasi, Pemerintah Indonesia telah mempunyai payung hukum yang mengatur standar baku kegiatan Bioremediasi dalam mengatasi permasalahan lingkungan akibat kegiatan pertambangan dan perminyakan serta bentuk pencemaran lainnya (logam berat dan pestisida) melalui Kementerian Lingkungan Hidup, Kep Men LH No.128 tahun 2003, tentang tatacara dan persyaratan teknis dan pengelolaan limbah minyak bumi dan tanah terkontaminasi oleh minyak bumi secara biologis (Bioremediasi) yang juga mencantumkan bahwa bioremediasi dilakukan dengan menggunakan mikroba lokal.

Pada dasarnya, pengolahan secara biologi dalam pengendalian pencemaran air, termasuk upaya bioremediasi, dengan 
memanfaatkan bakteri bukan hal baru namun telah memainkan peran sentral dalam pengolahan limbah konvensional sejak tahun 1900-an (Mara, Duncan and Horan, 2003). Saat ini, bioremediasi telah berkembang pada pengolahan air limbah yang mengandung senyawa-senyawa kimia yang sulit untuk didegradasi dan biasanya dihubungkan dengan kegiatan industri, antara lain logam-logam berat, petroleum hidrokarbon, dan senyawa-senyawa organik terhalogenasi seperti pestisida dan herbisida (Tortora, 2010), maupun nutrisi dalam air seperti nitrogen dan fosfat pada perairan tergenang (Great Lakes Bio Systems. Inc. Co Orb-3.com/). Pengembangan IPTEK dalam bioremediasi untuk detoksifikasi atau menurunkan polutan dalam pengendalian pencemaran air telah menjadikan metoda ini menjadi lebih menguntungkan dibandingkan dengan metoda yang menggunakan bahan kimia. Bahkan, saat ini, flokulan umum yang berbahan baku Alum untuk menurunkan bahan pencemar air sungai telah bisa digantikan dengan bioflokulan yang mikroorganismanya diisolasi dari proses lumpur aktif dan diketahui dapat menurunkan turbiditi sebesar 84-94\% (Buthelezi et al, 2009). Selain itu, kehandalan mikroba termasuk diantaranya bakteri, jamur, dan protozoa dalam pengolahan air limbah dan peranannya dalam menjaga keseimbangan ekologis perairan sudah banyak dielaborasi (Gerardi., 2006).

\section{Prinsip Dasar}

Pengolahan air tercemar secara biologi pada prinsipnya adalah meniru proses alami self purification di sungai dalam mendegradasi polutan melalui peranan mikroorganisma. Peranan mikroorganisma pada proses self purification ini pada prinsipnya ada dua (Gambar 1) yaitu: pertumbuhan mikroorganisma menempel dan tersuspensi.

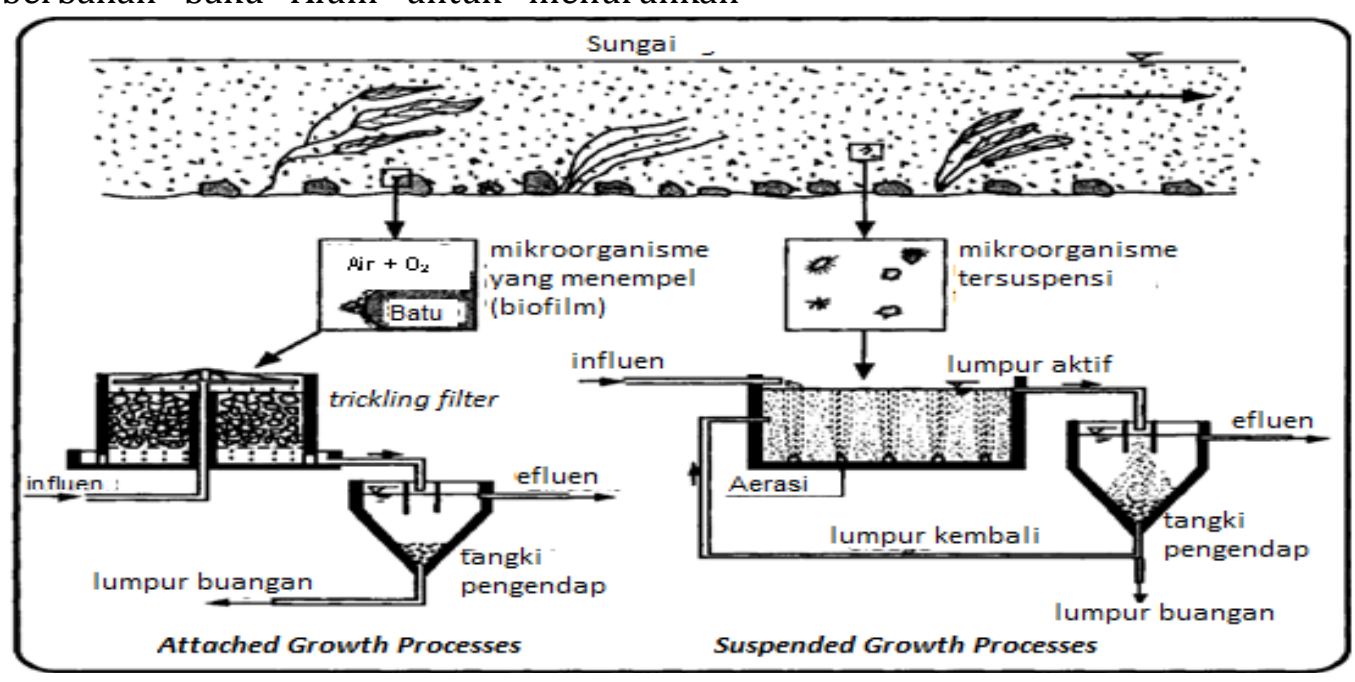

Gambar 1. Proses self-purification di sungai yang diadopsi pada IPAL penduduk (Mudrack and Kunst, 1986; dalam Paul Lessard and Yann Le Bihan, 2003)

\section{a. Pertumbuhan menempel}

Mikroorganisme ini keberadaannya menempel pada suatu permukaan misalnya pada batuan ataupun tanaman air. Selanjutnya diaplikasikan pada Instalasi Pengolahan Air Limbah (IPA) misalnya dengan sistem trickling filter. Selama pengolahan aerobik air limbah domestik, genus bakteri yang sering ditemukan berupa Gram-negatif berbentuk batang heterotrofik organisme, termasuk Zooglea, Pseudomonas, Chromobacter, Achromobacter, Alcaligenes dan
Flavobacterium. Filamentous bakteri seperti genera Beggiatoa, Thiotrix dan Sphaerotilus juga ditemukan dalam biofilm, sebagaimana organisme seperti Nitrosomonas dan nitrifikasi Nitrobacter.

\section{b. Pertumbuhan mikroorganisma yang tersuspesi}

Mikroorganisme ini keberadaannya dalam bentuk suspensi di dalam air yang tercemar. Selanjutnya diaplikasikan pada IPAL dengan sistem lumpur aktif 
konvensional menggunakan bak aerasi maupun sistem SBR (Sequence Batch Reactor). Berbeda dengan mikroorganisma yang menempel, sistem pertumbuhan mikroorganisma yang tersuspensi terdiri dari agregat mikroorganisma yang pada umumnya tumbuh sebagai flocs dalam kontak dengan air limbah pada waktu pengolahan. Agregat atau flocs, yang terdiri dari berbagai spesies mikroba, berperan dalam penurunan polutan. Umumnya spesies mikroba ini terdiri dari bakteri, protozoa dan metazoa. Pada sistem kolam stabilisasi, organisme phototrophic, yang memanfaatkan berbagai akseptor elektron, dapat dimanfaatkan untuk mencapai pengolahan yang baik dengan mengabaikan masukan energi. Kumpulan paper yang menceritakan berbagai metoda pengolahan air limbah yang menggunakan mikroorganisma serta permasalahannya dielaborasi dalam Mara, Duncan and Horan (2003). Pengembangan penerapan kedua proses tersebut dalam teknologi pengolahan air limbah dapat digabungkan berupa hybrid reactor (Gambar 2).

Pada akhirnya, peniruan proses alami self purification di sungai dalam mengdegradasi polutan baik melalui mikroorganisma yang menempel maupun mikroorganisma yang tersuspensi untuk bioremediasi air tercemar memerlukan beberapa tahapan. Tahapan tersebut meliputi: isolasi bakteri, pengujian bakteri dalam mengdegradasi zat pencemar, identifikasi, dan perbanyakan bakteri. Bagi pengggunaan bakteri indigenous, seperti yang dipersyaratkan oleh Kep Men LH No.128 (2003), tahap isolasi bakteri merupakan langkah awal yang harus diperhatikan.

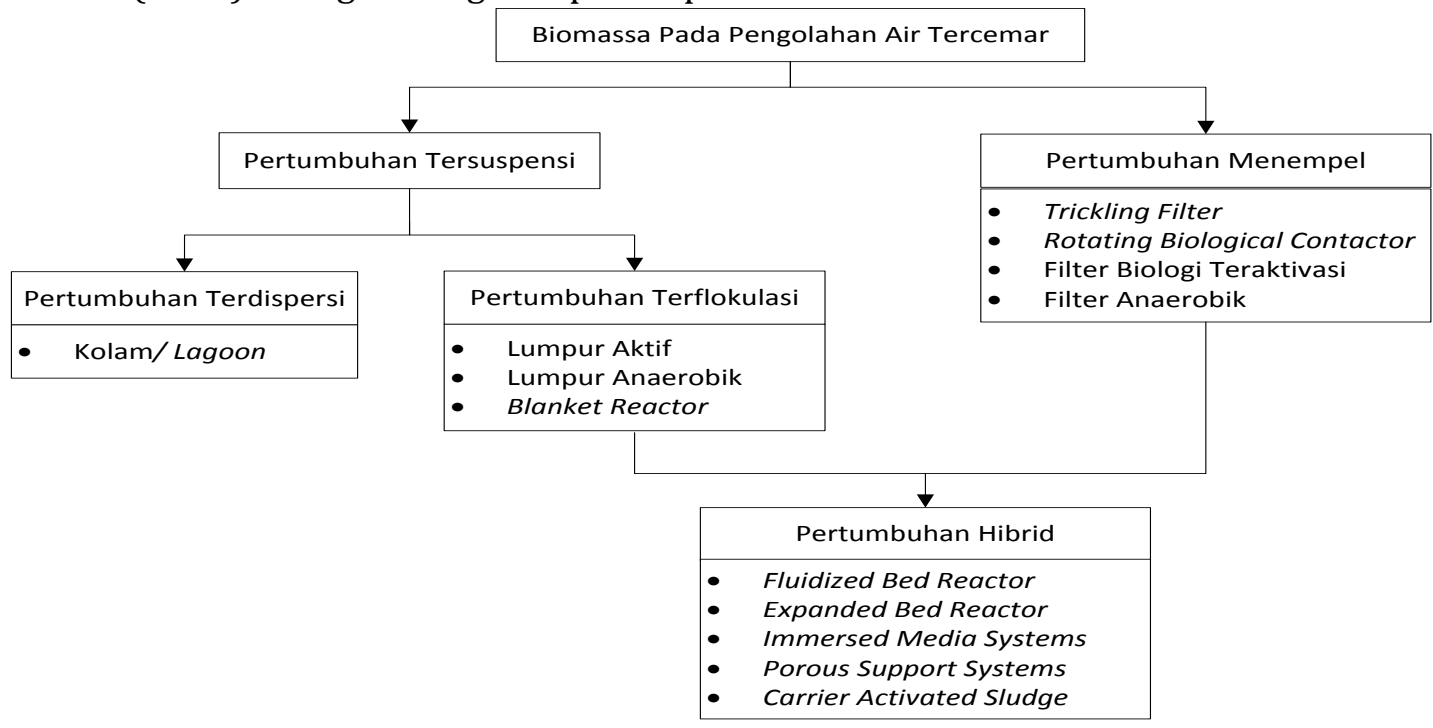

Gambar 2. Sistematika bentuk biomasa dalam sistem IPAL (Senthilnathan and Ganczarczyk, 1990, dalam Lessard and Bihan, 2003)

\section{Teknik Isolasi Bakteri}

Isolasi bakteri yang baik dan benar dapat menentukan bakteri yang cocok dalam proses remediasi air limbah yang diinginkan. Oleh karena itu prinsip pemilihan bakteri hasil isolasi dapat memberikan kinerja penurunan kadar polutan yang optimal (Thompson et al, 2005). Karena secara alami jumlah bakteri yang diinginkan terdapat dalam jumlah sedikit, malah lebih banyak bakteri yang tidak diinginkan, maka diperlukan proses isolasi untuk memperbanyak bakteri yang dimaksud (Barrow. and Feltham , 2003). Tujuan mengisolasi bakteri adalah untuk mendapatkan bakteri yang diinginkan dengan cara mengambil sampel mikroba dari lingkungan yang ingin diteliti. Dari sampel tersebut kemudian dikultur/dibiakkan dengan menggunakan media universal atau 
media selektif, tergantung tujuan yang ingin dicapai ( Tortora, 2010).

Bahan nutrisi dipersiapkan untuk pertumbuhan bakteri di laboratorium yang disebut kultur media. Beberapa bakteri dapat tumbuh dengan baik pada hampir semua media kultur; lainnya memerlukan media kultur khusus yang pada akhirnya akan ada suatu pertumbuhan yang disebut inokulum. Untuk tujuan tersebut diperlukan media yang diperkaya (enrichment culture) untuk memperbanyak bakteri yang dimaksud. Beragam media untuk isolasi jenis-jenis bakteri diuraikan secara detail pada Handbook of Media for Environmental Microbiology (Atlas dan Ronald, 2005), serta pekerjaan laboratorium dan peralatan yang dibutuhkan (Benson, 2001; Seiler, 2005). Pada medium yang diperkaya, termasuk juga media selektif, biasanya menyediakan nutrisi dan kondisi lingkungan yang mendukung pertumbuhan mikroba yang diinginkan tetapi menghambat bakteri lainnya (Tortora, 2010).

Setelah itu, media yang mengandung mikroorganisma diinginkan tersebut selanjutnya diinkubasi selama beberapa hari, kemudian sejumlah kecil inokulum dipindahkan ke lain media dengan komposisi media yang sama. Setelah serangkaian transfer tersebut, mikroorganisma yang masih hidup akan terdiri dari bakteri yang mampu melakukan metabolisme bahan organik. Setelah populasi bakteri bertambah dilakukan isolasi pada medium agar yang diinkubasi selama 3 hari. Dari hasil inkubasi tersebut diperoleh koloni-koloni bakteri untuk selanjutnya akan diambil koloni yang dominan untuk diamati dan dibuat sub kultur murninya untuk digunakan dalam penurunan zat pencemar (Gambar 3)

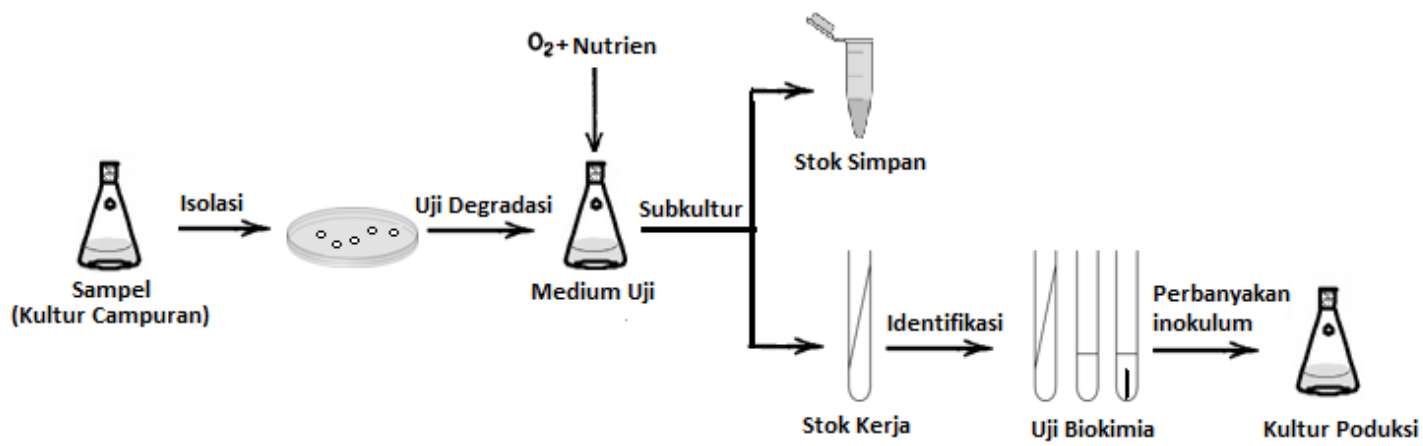

Gambar 3 . Proses isolasi, uji degradasi, identifikasi, dan perbanyakan bakteri

\section{APLIKASI BIOREMEDIASI}

\section{Isolasi bakteri dan Penurunan Kadar Pencemar}

Saat ini penelitian dan aplikasi bioremediasi untuk air tercemar dapat dibedakan menjadi dua, yaitu bakteri indigenous dan cakteri "commercial product.

\section{a) Bakteri Indigenous}

Bakteri indigenous merupakan hasil isolasi bakteri yang dilakukan oleh laboratorium yang bersangkutan. Isolat terbaik yang dipilih dapat dikombinasikan dalam suatu konsorsium. Hasil isolasi dan seleksi bakteri indigenous yang berasal dari lumpur Sungai Siak didapatkan 6 isolat bakteri yang dapat mereduksi logam $\mathrm{Pb}$. Bakteri tersebut terdiri dari: Microccocus, Corynebacterium, Phenylo- bacterium, Enhydrobacter, Morrococcus, Flavobacterium dengan jumlah total bakteri berkisar antara: $3,0 \times 10^{7}$ sampai $1,5 \times 10^{8} \mathrm{sel} / \mathrm{ml}$ (Sri, Dewi, dan Suwondo, 2005). Selain berpotensi dalam penurunan logam, bakteri indigenous lain yang berasal dari Rumah Pemotongan Hewan (RPH) juga mempunyai kemampuan untuk menurunkan pencemar organik, seperti isolat hasil penelitian Suyasa (2007) yang mendapatkan 17 isolat bakteri yang berasal dari RPH mempunyai kemampuan 
menurunkan COD 63\% waktu retensi 7 hari. Selain dari lumpur sungai, bakteri untuk bioremediasi air juga dapat diperoleh dari air dan sedimen danau atau tambak udang. Dengan melakukan isolasi dan seleksi bakteri yang berasal air dan lumpur Danau Maninjau didapatkan 2 isolat bakteri yang dapat mereduksi sulfida, dan 7 isolat bakteri untuk mereduksi amonia (Rusnam; Efrizal; Bustanul , 2009). Seperti juga di danau yang merupakan ekosistem perairan tergenang (lentic), kolam tambak udang juga mempunyai potensi bakteri remediasi. Dari Isolasi dan seleksi bakteri yang berasal dari tambak udang di daerah Karawang, Jawa Barat (Muhammad dan Widiyanto, 2008) menyimpulkan bahwa bakteri yang berasal dari perairan tambak udang tersebut mampu menjaga kestabilan konsentrasi amonia dan nitrit, sehingga konsentrasinya masih berada pada batas aman untuk budidaya. Tabel 1 berikut adalah beberapa contoh penggunaan isolat indigenous pada pengendalian badan air

tercemar

Tabel 1. Beberapa contoh penggunaan isolat indigenous pada pengendalian badan air tercemar

\begin{tabular}{|c|c|c|c|c|}
\hline Identitas bioremediator & Sumber & Digunakan pada & Metode aplikasi & Referensi \\
\hline $\begin{array}{l}2 \text { isolat bakteri untuk } \\
\text { mereduksi sulfida } \\
7 \text { isolat bakteri untuk } \\
\text { mereduksi amonia >35\% (dari } \\
\text { konsentrasi awal } 500 \mathrm{mg} / \mathrm{L} \text { ) } \\
\text { Microccocus, Corynebacterium, } \\
\text { Phenylo- bacterium, Enhydro- } \\
\text { bacter, Morrococcus, } \\
\text { Flavobacterium }\end{array}$ & $\begin{array}{l}\text { Perairan tambak } \\
\text { udang } \\
\text { air dan sediment } \\
\text { danau Maninjau }\end{array}$ & $\begin{array}{l}\text { perairan tambak } \\
\text { udang windu dosis } 50 \\
\text { L } \\
\text { Menurunkan kadar } \\
\text { nitrat dan nitrit di } \\
\text { tamvak udang } \\
\text { Sulfida dan ammonia. } \\
\text { mereduksi amonia } \\
>35 \quad \text { (dari } \\
\text { konsentrasi awal } 500 \\
\text { mg/L) }\end{array}$ & $\begin{array}{l}\text { Ditebar di tambak } \\
\text { dengan dosis } 50 \mathrm{~L} / \mathrm{ha} \\
\text { (udang umur } 30-60 \\
\text { hari) dan } \\
100 \mathrm{~L} / \mathrm{h} \text { ( } 60 \text { - } 120 \text { hari) } \\
\text { dengan kepadatan } \\
\text { populasi } 10^{9} \mathrm{upk} / \mathrm{mL} \\
\text { setiap } 10 \text { hari } \\
\text { Laboratorium: } \\
\text { Petri disk } \\
\text { Erlenmeyer } \\
\text { Laboratorium, } \\
\text { Petri disk } \\
\text { Jumlah total bakteri } \\
\text { pengikat Pb: } 3,0 \times 10^{7} \\
\text { sampai } 1,5 \times 10^{8} \mathrm{sel} / \mathrm{ml}\end{array}$ & $\begin{array}{l}\text { Badjoeri } \\
\text { Muhammad dan } \\
\text { Tri Widiyanto, } \\
2008 \\
\text { Rusnam; Efrizal; } \\
\text { Arifin Bustanul, } \\
2009 \\
\\
\text { Wulandari Sri, } \\
\text { Nila Fitri Dewi, } \\
\text { dan Suwondo, } \\
2005\end{array}$ \\
\hline $\begin{array}{l}17 \text { isolat dari } \\
\text { Rumah Pemotongan Hewan } \\
(\mathrm{RPH})\end{array}$ & $\begin{array}{l}\text { Sedimen Perairan } \\
\text { Tercemar dan Bak } \\
\text { Pengolahan Limbah }\end{array}$ & $\begin{array}{l}\text { Penurunan COD } 63 \% \\
\text { waktu retensi } 7 \text { hari }\end{array}$ & $\begin{array}{l}\text { Laboratorium: } \\
\text { Petri disk } \\
\text { Erlenmeyer }\end{array}$ & $\begin{array}{l}\text { Suyasa, I W.B. } \\
2007,\end{array}$ \\
\hline $\begin{array}{l}\text { Bacillus subtilis } \\
\text { Exiguobacterium acetylicum } \\
\text { Klebsiella terrigena } \\
\text { Staphylococcus aureus } \\
\text { Pseudomonas pseudoalcaligenes } \\
\text { Pseudomonas plecoglossicida }\end{array}$ & Activated sludge & $\begin{array}{l}\text { Penurunan Turbidity } \\
84.07-93.56 \% \text { at } 10 \\
\text { ppm }\end{array}$ & Tube test & $\begin{array}{l}\text { Buthelezi, et al, } \\
2009\end{array}$ \\
\hline $\begin{array}{l}\text { gram-positive bacillus (GPB), } \\
\text { gram-positive cocci (GPC), } \\
\text { gram-negative bacillus } \\
\text { (GNB) and gram-negative cocci } \\
\text { (GNC) } \\
\text {. }\end{array}$ & $\begin{array}{l}\text { Sewage treatment } \\
\text { plants }\end{array}$ & $\begin{array}{l}\text { Mendapatkan isolasi } \\
\text { bakteri untuk } \\
\text { pengolahan air limbah } \\
\text { penduduk }\end{array}$ & $\begin{array}{l}\text { Laboratorium, } \\
\text { Petri disk } \\
\text { Kepadatan populasi } \\
10^{4}-10^{9} \text { upk/mL } \\
\text { Total isolate } 46 \text { : } \\
22 \text { isolat GPB dan GPC } \\
19 \text { isolat f GNP and GNC, } \\
5 \text { isolat tidak } \\
\text { terderterminasi }\end{array}$ & $\begin{array}{l}\text { Jalal, K.C.A, et al, } \\
2006\end{array}$ \\
\hline
\end{tabular}

\section{b) Bakteri "commercial product"}

Selain bakteri indigenous, perkembangan IPTEK bioremediasi menjadikan produksi mikroorganisma maupun enzim dipasaran komersial semakin mudah didapatkan. Produk komersial untuk bioremediasi biasa dipergunakan untuk menjaga kualitas air danau (pond), algal bloom, penurunan nitrat-fosfat, peningkatan 
kecerahan (Great Lakes Bio Systems. Inc. Co Orb-3). Selain untuk perairan tergenang (lentic), produk komersial juga telah diterapkan pada perairan mengalir (lotic). Produk ACF32 dan BioAktiv digunakan di Sungai Bintangor- Malaysia (Beng, 2007a) yang dapat menurunkan kadar BOD, COD, TSS, Total-N, Total-P dalam air sebesar rata- rata 50\%. Sedangkan produk AquaClean ${ }^{\circledR}$ (Beng , 2007b) dipakai dalam bioremediasi Sungai Xiba di China (Yudianto and Yuebo, 2010). Beberapa contoh lain penelitian bioremediasi yang berasal dari bakteri komersial dapat dilihat pada tabel 2 .

Tabel 2. Beberapa contoh penggunaan isolat Bakteri "commercial product" pada pengendalian badan air tercemar dan budidaya perikanan

\begin{tabular}{|c|c|c|c|c|}
\hline Identitas Bioremediator & Sumber & Digunakan & $\begin{array}{l}\text { Metode } \\
\text { aplikasi }\end{array}$ & Referensi \\
\hline \multicolumn{5}{|l|}{ Pada budidaya perikanan } \\
\hline Bacillus sp. 48 & Common snook & Centropomus undecimalis & $\begin{array}{l}\text { Dimasukan ke } \\
\text { dalam air; } \\
\text { mengurangi } \\
\text { tingkat salinitas }\end{array}$ & $\begin{array}{l}\text { Antony and R. Philip } \\
\text { (2006) }\end{array}$ \\
\hline Bacillus sp. & Produk komersial & Penaeids & Air & $\begin{array}{l}\text { Antony and R. Philip } \\
\text { (2006) }\end{array}$ \\
\hline Bacillus sp. & Produk komersial & Channel catfish & $\begin{array}{l}\text { Disebarkan } \\
\text { pada air kolam }\end{array}$ & $\begin{array}{l}\text { Antony and R. Philip } \\
\text { (2006) }\end{array}$ \\
\hline $\begin{array}{l}\text { Kultur campuran, } \\
\text { kebanyakan Bacillus sp. }\end{array}$ & Produk komersial & Brachionus plicatilis & $\begin{array}{l}\text { Dicampurkan } \\
\text { pada air }\end{array}$ & $\begin{array}{l}\text { Antony and R. Philip } \\
\text { (2006) }\end{array}$ \\
\hline Roseobacter sp. BS 107 & Tidak diketahui & Larva Scallop & $\begin{array}{l}\text { Dicampurkan } \\
\text { pada air }\end{array}$ & $\begin{array}{l}\text { Antony and R. Philip } \\
\text { (2006) }\end{array}$ \\
\hline \multicolumn{5}{|l|}{ Pada badan air } \\
\hline Enzymes \& Bacteria & Danau & $\begin{array}{l}\text { Di danau } \\
\text { Mengurangi kekeruhan dan } \\
\text { pencemar organik }\end{array}$ & $\begin{array}{l}\text { Dicampurkan } \\
\text { pada air danau }\end{array}$ & $\begin{array}{l}\text { Great Lakes Bio Great } \\
\text { Lake Bio Systems. Inc. } \\
\text { Co Orb-3 }\end{array}$ \\
\hline ACF32 dan BioAktiv & $\begin{array}{l}\text { OCHEM EAST SDN. } \\
\text { BHD. }\end{array}$ & $\begin{array}{l}\text { Di sungai } \\
\text { Penurunan BOD, COD }\end{array}$ & $\begin{array}{l}\text { Dimasukan ke } \\
\text { dalam air sungai } \\
\text { secara periodik }\end{array}$ & Beng G.K., 2007a \\
\hline Tidak diketahui & AquaClean $®$ & $\begin{array}{l}\text { Penurunan parameter: BOD, } \\
\text { COD, TSS, TN, TP, Rata-rata } \\
50 \%\end{array}$ & $\begin{array}{l}\text { Penebaran } \\
\text { bakteri } \\
\text { AquaClean } ® \text { di } \\
\text { sungai }\end{array}$ & Beng G.K., 2007b \\
\hline $\begin{array}{l}\text { - Kumpulan Species Bacillus, } \\
\text { Aerob dan facultatif } \\
\text { anaerobe } \\
\text { - Produksi Enzym Bakteri: } \\
\text { Amylase, Protease, Lipase, } \\
\text { Esterase, Urease, Cellulase, } \\
\text { Xylanase }\end{array}$ & $\begin{array}{l}\text { Environmental } \\
\text { Leverage Inc. } \\
-\quad \text { MicroBlock } \\
-\quad \text { Microclear } 101\end{array}$ & $\begin{array}{l}\text { Di danau } \\
\text { Kontrol pertumbuhan alga } \\
\text { Di sungai } \\
\text { Bioaugmentasi di saluran }\end{array}$ & $\begin{array}{l}\text { Dimasukan ke } \\
\text { dalam air }\end{array}$ & $\begin{array}{l}\text { Environmental } \\
\text { Leverage Inc. }\end{array}$ \\
\hline $\begin{array}{l}\text { Bacillus subtilis, Bacillus } \\
\text { licheniformis, Pseudomonas } \\
\text { aeruginosa, Pseudomonas } \\
\text { stutizeri, Escherichia } \\
\text { hermanii and Pseudomonas } \\
\text { fluorescens }\end{array}$ & $\begin{array}{l}\text { 1. a commercial } \\
\text { bioadditive } \\
\text { 2. activated sludge }\end{array}$ & $\begin{array}{l}\text { Penurunan : 55\% COD, } \\
62 \% \text { BOD } \\
\text { Penurunan : } 89 \% \text { COD, } \\
97 \% \text { BOD }\end{array}$ & $\begin{array}{l}\text { The pilot-scale } \\
\text { channel reactor } \\
(1.20 \mathrm{~m} \times 0.7 \mathrm{~m} \mathrm{x} \\
0.25 \mathrm{~m}), \text { feed } \\
\text { rate } 2,5 \mathrm{~L} / \mathrm{jam}\end{array}$ & Silva, M. C. L. et al, \\
\hline
\end{tabular}

\section{Identifikasi bakteri}

Identifikasi dapat dilakukan dengan beberapa cara termasuk : Pengamatan morfologi sel, pewarnaan gram, dan uji biokimia. Beberapa contoh morfologi sel bakteri yang berasal dari peternakan sapi di Kabupaten Bandung (Gambar 4). Selain berdasarkan morfolofi, bakteri juga dibedakan menjadi 3 bentuk meliputi: Bentuk bulat (kokus), Bentuk batang (basil), 
dan Bentuk spiral (Pelczar dan Chan, 2006; Bergey's, 2005, Michael .,2006).

Beberapa contoh bentuk bakteri dan pewarnaan yang berasal dari sewage treatment di Malaysia dapat dilihat pada gambar 5.

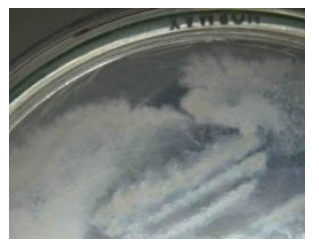

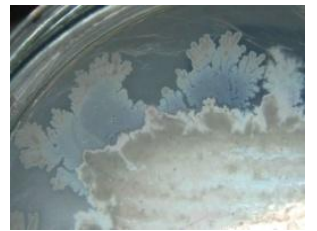

Gambar 4. Morfologi sel dari peternakan sapi di Kabupaten Bandung (Puslitbang SDA, 2011)
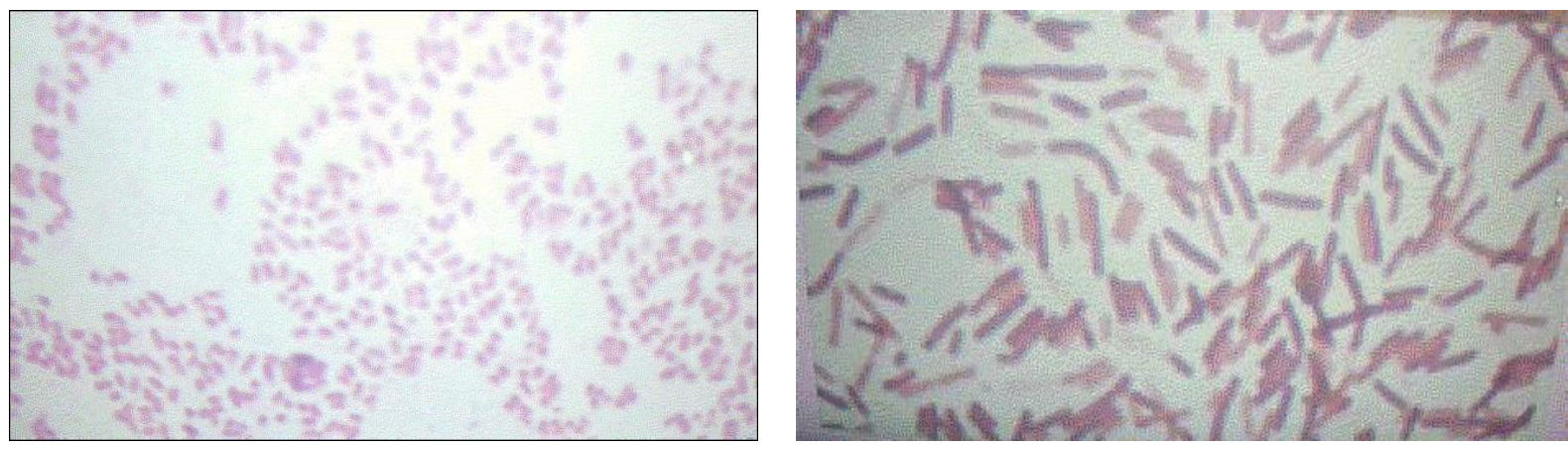

Gambar 5. bentuk bakteri dan pewarnaan yang berasal dari sewage treatment di Malaysia Gram positif -kokus (kiri) dan Gram positif- basil (kanan) Jalal, K.C.A, et al, 2006

Beberapa contoh dari hasil isolasi dan identifikasi indeginous bakteri didapatkan jenis Microccocus, Corynebacterium, Phenylo- bacterium, Enhydro- bacter, Morrococcus, Flavobacterium. Selain bakteri indigenous tersebut, bakteri "commercial product" seperti jenis Bacillus, Pseudomonas, Escherichia, serta enzym Amylase, Protease, Lipase, Esterase, Urease, Cellulase, Xylanase, juga diketahui dapat mendegradasi bahan pencemar organik (BOD, COD) di sungai,

Medium pengembangan inokulum harus cukup serupa dengan medium produksi. Hal ini dimaksudkan untuk meminimalkan periode adaptasi dengan mereduksi fase lag. Perbanyakan bakteri atau pengembangan inokulum ini merupakan proses untuk memproduksi inokulum dengan jumlah yang besar sehingga menjaga keberlangsungan maupun degradasi nitrogen, fosfat, maupun kontrol pertumbuhan alga di danau.

\section{Perbanyakan bakteri}

Setelah didapatkan isolat yang diinginkan, uji degradasi, dan identifikasi bakteri, selanjutnya adalah membuat perbanyakan bakteri untuk uji skala lapangan. Perbanyakan bakteri atau pengembangan inokulum ini merupakan proses untuk memproduksi inokulum.

Perbanyakan bakteri indigenous dilakukan melalui tahapan: pembuatan kultur stok, pemeliharaan kultur, perbanyakan kultur tahap I, perbanyakan kultur tahap II, dan pembuatan kultur produksi. Contoh bagan alir perbanyakan bakteri indigenous dapat dilihat pada Gambar 6 dan 7. 


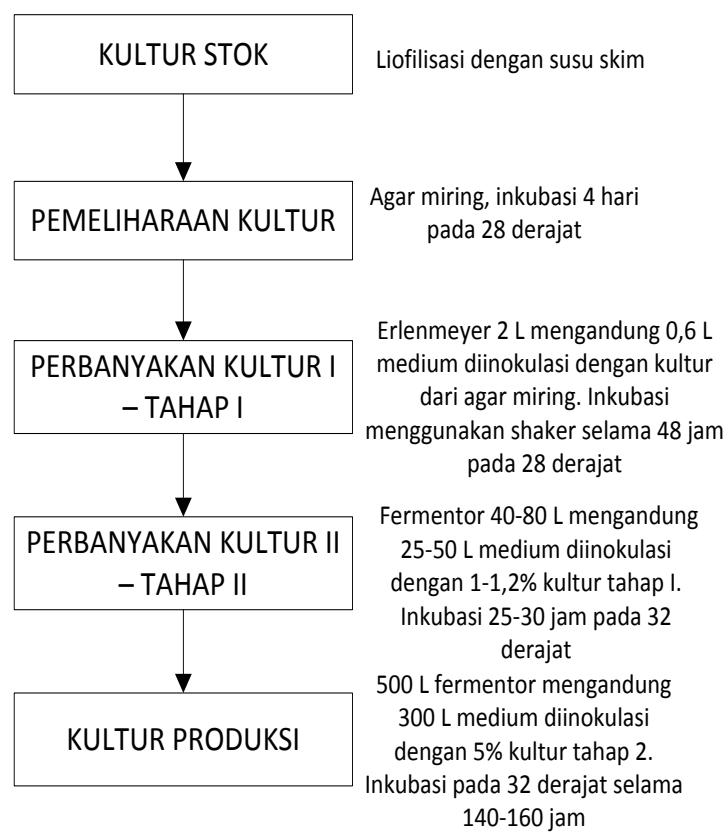

Gambar 6 Diagram Alir Pengembangan Inokulum untuk Program Skala Pilot Fermentasi Vitamin B12 Menggunakan Pseudomonas aeruginosa (Spalla et. al, 1989 dalam Astuti, 2009)

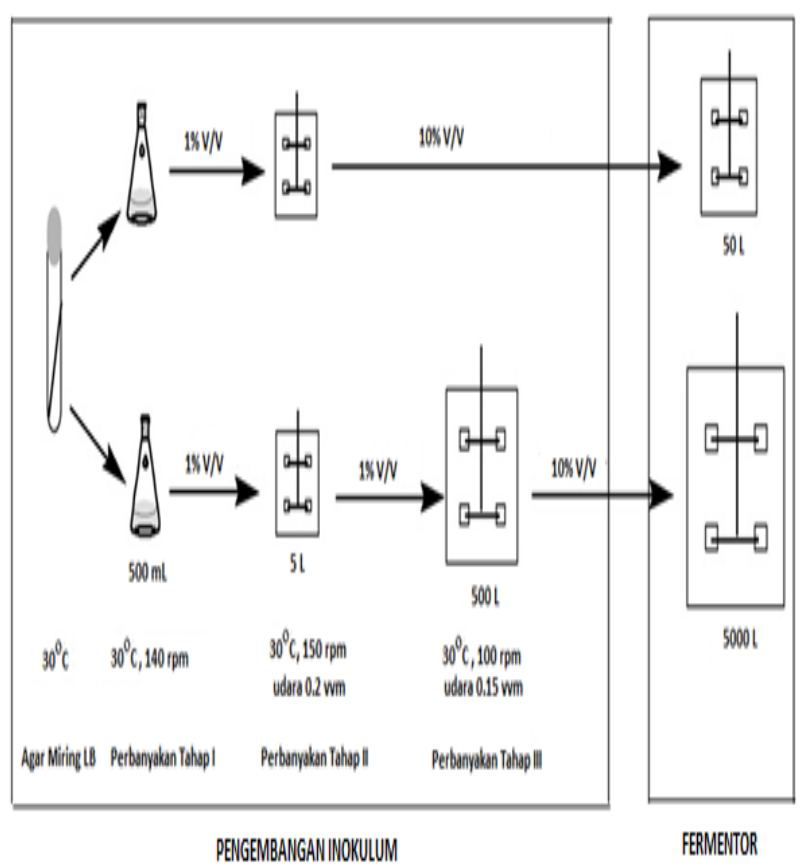

Gambar 7 diagram alir pengembangan inokulum bakteri menggunakan bakteri Klebsiella pneumoniae (Cheng , Ke-Ke, et al. 2007) 
Berbeda dengan perbanyakan bakteri indigenous, bakteri yang berasal dari commercial product pada umumnya hanya tinggal mengencerkan produk dengan dosis yang telah ditetapkan pada kemasannya (Great Lakes Bio Systems. Inc. co Orb-3.com; Environmental Leverage Inc.; Beng, 2007a, Beng , 2007b ). Sebagai contoh, diperlukan total 403 galon produk ACF32 dan $330 \mathrm{~kg}$ BioAktiv yang disebarkan ke sungai selama tiga bulan dalam rangka bioremediasi Sungai Bintangor sepanjang $650 \mathrm{~m}$ dengan lebar sungai antara 12 - 15 m (Beng., 2007a). Produk lainnya, untuk mengurangi kekeruhan di danau, produk Professional Enzymes \& Bacteria memerlukan dosis 0,5 galon per acre foot (1,5 ppm) dengan ulangan 2-4 kali setahun (Great Lakes Bio Systems. Inc. co Orb3.com)

\section{KESIMPULAN}

Teknologi bioremediasi dalam pengendalian badan air tercemar dapat dilakukan melalui proses: isolasi, pengujian bakteri dalam mengdegradasi zat pencemar, identifikasi bakteri, dan perbanyakan bakteri. Isolat bakteri tersebut dapat berasal dari bakteri "indigenous" atau dari "commercial product". Baik bakteri "indigenous" maupun commercial product" dapat mereduksi bahan pencemar logam $\mathrm{Pb}$, nitrat, nitrit, bahan organik (COD), sulfida, kekeruhan, dan amonia di sungai maupun danau. Perbanyakan bakteri indigenous dilakukan melalui tahapan: pembuatan kultur stok, pemeliharaan kultur, perbanyakan kultur tahap I, perbanyakan kultur tahap II, dan pembuatan kultur produksi. Sedangkan perbanyakan bakteri yang berasal dari commercial product tinggal mengencerkan produk dengan dosis yang telah ditetapkan pada kemasannya

\section{DAFTAR PUSTAKA}

Antony. S.P. and R. Philip (2006) Bioremediation in Shrimp Culture Systems. NAGA, World Fish Center Quarterly Vol. 29 No. 3 \& 4 Jul-Dec 2006

Astuti, Dea Indriani. 2009. Kuliah Prinsip Teknik Fermentasi. Bandung : ITB

Atlas, Ronald M., 2005. Handbook of media for environmental microbiology, $2^{\text {nd }}$ ed. ISBN 0-84933560-4. CRC Press

Badjoeri, M, Tri Widiyanto. 2008. Penggunaan Bakteri Nitrifikasi untuk Bioremediasi dan Pengaruhnya terhadap Konsentrasi Ammonia dan Nitrit di Tambak Udang. ISSN 0125-9830. Jurnal Oseanologi dan Limnologi Indonesia Vol. 34 (2) : 261-278.
Beng G.K., 2007a Report for Bio-remediation of Polluted Waters Sungai Bintangor, Kuching, Sarawak, with Aqua Clean ${ }^{T M}$ and BioAktiv. OCHEM EAST SDN. BHD. Sarawak

Beng G.K., 2007b. Cost Effective Bioremediation of Polluted Rivers, Lagoons and Lakes for a Sustainable Water Supply Source. Technical Paper KWP June 2007 Conference Karachi. Pakistan

BPLHD DKI Jakarta, 2002. Data Pemantauan Kualitas Air Sungai di Propinsi DKI Jakarta, Jakarta, 2002.

Barrow, G.I. and Feltham R.K.A.; ed, 2003, Cowan and Steel's manual for identification of medical bacteria -3rd ed. / edited and rev.

Buthelezi, S. P., Olaniran, A. O. and Pillay, B., 2009, Turbidity and microbial load removal from river water using bioflocculants from indigenous bacteria isolated from wastewater in South Africa, African Journal of Biotechnology Vol. 8 (14), pp. 3261-3266, 20 July, 2009. ISSN 1684-5315 (C) 2009 Academic Journals

Benson, 2001, Microbiological Applications Lab Manual,Eighth Edition, The McGraw-Hill Companies.

Barrow, G.I. and. Feltham, R.K.A; ed, 2003, Cowan and Steel's manual for identification of medical bacteria 3rd ed. CAMBRIDGE UNIVERSITY PRESS.

BERGEY'S MANUAL OF Systematic Bacteriology, 2005, $2^{\text {nd }}$ ed, ISBN-10: 0-387-24145-0ISBN-13: 978-0387-24145-6, Springer

Cheng , Ke-Ke; Zhang, Jian-An ; Liu, De-Hua; Sun, Yan ; Liu, Hong-Juan; Yang, Ming-De; Xu, Jing-Ming. 2007. Pilot-Scale Production of 1,3-Propanediol Using Klebsiella pneumoniae. Process Biochemistry 42 (2007) 740-744.

Environmental Leverage Inc. Microclear 101 For Algae ControlPRODUCT BULLETIN, remediation of river and lakes

Gerard J. Tortora, Berdell R. Funke, Christine L. Case. - 10th ed, 2010, Microbiology: an introduction.

Great Lakes Bio Systems. Inc. .co Orb3.com/LakeAndPond Orb-3 Professional Enzymes \& Bacteria are the total solution.

Gerardi, M.H. 2006. Wastewater Bacteria. New Jersey. John Willey.

Hendrawan Diana 2005. Kualitas Air Sungai dan Situ di DKI Jakarta, Makara, Teknologi, Vol. 9, No.1, April 2005:13-19

Jalal, K.C.A.,; Zahangir Alam, Md.; Suleyman A; Muyibi and Jamal P.; 2006, Isolation and Purification of Bacterial Strains from Treatment Plants for Effective and Efficient Bioconversion of Domestic Wastewater Sludge. American Journal of Environmental Sciences 2 (1): 1-5, 2006 ISSN 1553-345X 
Jürg P. Seiler, 2005, Good Laboratory Practice - the Why and the How, ISBN 3-540-25348-3 SpringerVerlag Berlin Heidelberg New York.

Keputusan Menteri Negara Lingkungan Hidup No. 51/MENLH/10/1995 Tentang Baku Mutu Limbah Cair Bagi Kegiatan Industri.

Keputusan Menteri Negara Lingkungan Hidup No. 128 Tahun 2003. Tata Cara dan Persyaratan Teknis dan Pengelolaan Limbah Minyak Bumi dan Tanah Terkontaminasi oleh Minyak Bumi secara Biologis (Bioremediasi).

Kementerian Lingkungan Hidup, 2010, Status Lingkungan Hidup Indonesia, Jakarta

Mara, Duncan and Horan,N.J, 2003 Handbook of water and wastewater microbiology, ISBN 0-12470100-0. Elsevier

Pusat Litbang Sumber Daya Air, 2011, Teknologi Pengendalian Kualitas Air Sungai Tercemar dan Air Limbah, Konsep Laporan Akhir

Peraturan Pemerintah No. 82 Th. 2001, tentang Pengelolaan Kualitas Air dan Pengendalian Pencemaran Air

Peraturan Menteri Negara Lingkungan Hidup No. 13 Tahun 2010, tentang Upaya Pemantauan Lingkungan Hidup dan Upaya Pengelolaan Lingkungan Hidup dan Surat Pernyataan Kesanggupan Pengelolaan dan Pemantauan Lingkungan Hidup;

Paul Lessard and Yann Le Bihan, 2003, Introduction to Microbiological Wastewater Treatment, Fixed film processes, Handbook of water and wastewater microbiology, Ed Duncan Mara and Hogan, Elsevier. ( 317-336)

Pelczar, Michael J dan Chan, E.C.S. 2006. Dasar-Dasar Mikrobiologi Jilid 1. Jakarta : Penerbit Universitas Indonesia.

Rusnam, Efrizal, Arifin Bustanul. 2009. Teknik Bioremediasi Pengendalian Pencemaran Air
Danau Maninjau Sumatera Barat. Penelitian Hibah Strategis Nasional. Universitas Andalas.

Silva. C. L. ; Barbosa, C. M. B. M.; Silva. , V. L. ; Pons. M.N.; Motta Sobrinho. , M. A, EVALUATION OF BACTERIAL BIOMASSES FOR THE POLLUTION TREATMENT OF THE DERBY-TACARUNA CANAL, $2^{\text {nd }}$ Mercosur Congress on Chemical Engineering, 4th Mercosur Congress on Process Systems Engineering, EMPROMER, Brazil

Suyasa, W.B. 2007. Isolasi Bakteri Pendegradasi Minyak/Lemak dari Beberapa Sedimen Perariran Tercemar dan Bak Pengolahan Limbah. Jurnal Bumi Lestari Vol. 7 (2) : 39-42.

Thompson Ian P.; Christopher J. van der Gast, Lena Ciric and Andrew C. Singer., 2005. Bioaugmentation for bioremediation: the challenge of strain selection, Environmental Microbiology (2005) 7(7), 909-915).

Undang-undang No:7/2004, tentang Sumber Daya Air

Wulandari Sri, Nila Fitri Dewi, dan Suwondo, 2005, IDENTIFIKASI BAKTERI PENGIKAT TIMBAL (Pb) PADA SEDIMEN DI PERAIRAN SUNGAI SIAK, Jurnal Biogenesis Vol. 1(2):62-65, 2005 (C) Program Studi Pendidikan Biologi FKIP Universitas Riau ISSN : 1829-5460

Yudianto, D, Xie Yuebo. 2010. Evaluasi Pemanfaatan Teknologi Bakteri dan Pemodelan Proses Biodegradasi dalam Pekerjaan Restorasi Sungai Xuxi, Kota Wuxi, China. Pengembangan Teknologi Bakteri untuk Restorasi Sungai, BAPPENAS. 